\section{Characterization of Benzoyl Saxitoxin Analogs from the Toxigenic Marine Dinoflagellate Gymnodinium catenatum by Hydrophilic Interaction Liquid Ion-Chromatography-Tandem Mass Spectrometry} Lorena M. Durán-Riveroll ${ }^{1 *}$, Bernd Krock ${ }^{2}$, Allan Cembella ${ }^{2}$, Javier Peralta-Cruz ${ }^{3}$, José J. Bustillos-Guzmán ${ }^{4}$ and Christine J. Band-Schmidt ${ }^{5}$
${ }^{1}$ CONACYT-Unidad Académica de Ecología y Biodiversidad Acuática, Instituto de Ciencias del Mar y Limnología, Universidad Nacional Autónoma de México, Mexico
City 04510, Mexico

${ }^{2}$ Alfred-Wegener-Institut, Helmholtz Zentrum für Polar-und Meeresforschung, Bremerhaven 27570, Germany

${ }^{3}$ Escuela Nacional de Ciencias Biológicas - Instituto Politécnico Nacional. Mexico City 11340, Mexico

${ }^{4}$ Centro de Investigaciones Biológicas del Noroeste, La Paz, B.C.S. 23096, Mexico

${ }^{5}$ Centro Interdisciplinario de Ciencias Marinas - Instituto Politécnico Nacional, La Paz, B.C.S. 23000, Mexico

*Corresponding author: Durán-Riveroll LM, CONACYT-Unidad Académica de Ecología y Biodiversidad Acuática, Instituto de Ciencias del Mar y Limnología, Universidad Nacional Autónoma de México, Mexico City 04510, Mexico, Tel: +52(55)5623-0222/44639; E-mail: Iduran@conacyt.mx

Received date: July 10, 2017; Accepted date: August 12, 2017; Published date: August 20, 2017

Copyright: (c) 2017 Durán-Riveroll LM, et al. This is an open-access article distributed under the terms of the Creative Commons Attribution License, which permits unrestricted use, distribution, and reproduction in any medium, provided the original author and source are credited.

\section{Abstract}

The chain-forming marine dinoflagellate Gymnodinium catenatum Graham has a remarkable capacity to produce a wide array of neurotoxic alkaloids associated with Paralytic Shellfish Poisoning (PSP). More than a decade ago, a completely new group of benzoyl saxitoxin analogs produced exclusively by this species was discovered, but the exact structural assignments and diversity among global population has remained elusive and unconfirmed in most cases. In the current study, fifteen among eighteen hypothetical benzoyl analogs were partially purified and identified from cultured isolates of $G$. catenatum from the Pacific coast of Mexico. Combined serial application of flash chromatography, preparative liquid chromatography and tandem mass spectrometry (LC-MS/MS) in multiple steps yielded a richness of benzoyl analogs that has not been reported nor confirmed before. Two sub-fractions were analyzed by ${ }^{1} \mathrm{H}-\mathrm{NMR}$; results from one fraction showed a probable AMX pattern for three protons, consistent with the presence of a 3,4-dihydroxylated benzoyl ring. These findings could be interpreted to correct the 2,4dihydroxylated structure previously proposed for the GCa benzoyl analog series. The revised and enhanced structural information on proposed benzoyl derivatives is necessary to provide further insights into biogeographical diversity of these potentially potent toxins produced by marine dinoflagellates and their role in seafood safety.
\end{abstract}

Keywords: Saxitoxin; Benzoyl analogs; Hydrophilic interaction chromatography; Preparative chromatography; Nuclear magnetic resonance

\section{Introduction}

Gymnodinium catenatum Graham is a chain-forming naked gymnodinoid dinoflagellate, notorious for formation of harmful algal blooms (HABs), and known for the production of paralytic shellfish toxins (PSTs), comprising a wide array of neurotoxic analogs of saxitoxin (STX). Blooms of this dinoflagellate have caused intoxications and death of marine fauna and human consumers of bivalve mollusks that have accumulated toxins via suspension-feeding upon the plankton [1]. This species is the only gymnodinioid dinoflagellate known to produce these toxins [2]. First described from the Gulf of California in 1943 [3], G. catenatum has been reported with increasing frequency from the 1970 s, and to date it has been found along the coastlines of all continents except Antarctica [2,4]. The species is widely distributed in both global hemispheres, but occurs primarily in temperate and sub-tropical waters, producing major blooms on the coast of Atlantic Iberia, Tasmania, southern Australia, and in Mexico along the Pacific coast [5].

Neurotoxins such as STX and its analogs are water soluble heterocyclic alkaloids that bear two guanidinium groups, and hence have shown high affinity and ion flux blockage capacity for voltage- gated sodium ion channels $\left(\mathrm{Na}_{\mathrm{v}}\right)$. The guanidinium group confers a positive charge to the molecule at physiological $\mathrm{pH}$, and this charge is directly implicated in their toxicity [6]. Toxin potency in mammalian systems greatly varies among different analogs depending on the substituent groups on the lateral chain, ranging in relative toxicity from the most potent, STX, to the least potent, N-sulfocarbamoyl derivatives [7].

A recent review on $G$. catenatum toxin analogs reports on studies conducted over the last several decades on the biogeographical relationships populations of this species based on their respective toxin profiles as biochemical markers [2]. The known carbamoyl, decarbamoyl, and sulfocarbamoyl analogs found among $G$. catenatum natural populations and cultured isolates, currently comprise 18 naturally occurring derivatives. Substantial variations in toxin content among various populations are reported to depend on physical oceanographic conditions, growth stages and nutritional factors [5,8-13]. The presence/absence of toxins, relative proportion and cell toxin content vary widely among cultured isolates and natural populations, but the toxin profile within individual strains is genetically determined and tends to remain rather fixed [13]. No known isolate produces the complete toxin spectrum, although all isolates typically produce more than one and usually several analogs [14]. 
Citation: Durán-Riveroll LM, Bernd Krock, Allan Cembella, Javier Peralta-Cruz, José J. Bustillos-Guzmán, et al. (2017) Characterization of Benzoyl Saxitoxin Analogs from the Toxigenic Marine Dinoflagellate Gymnodinium catenatum by Hydrophilic Interaction Liquid IonChromatography-Tandem Mass Spectrometry. Nat Prod Chem Res 5: 275. doi:10.4172/2329-6836.1000275

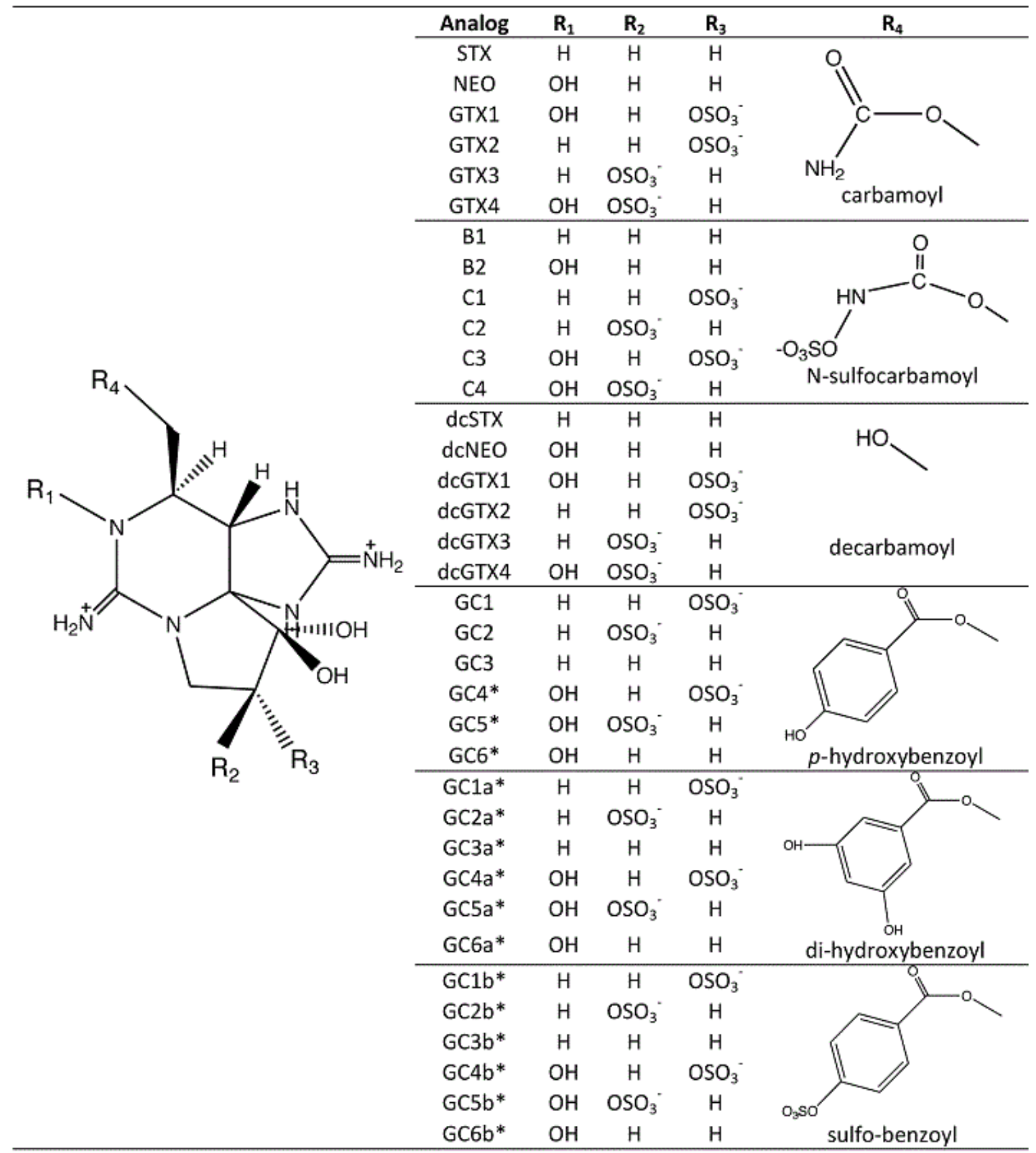

Figure 1: Chemical structure of saxitoxin and analogs produced by Gymnodinium catenatum. Structures marked with $\left(^{*}\right)$ were not fully characterized by NMR in previous studies but their probable structures were inferred based upon mass spectrometry [20]. According to our findings based upon mass spectrometry and NMR, we propose 3,4-dihydroxybenzoyl instead of 2,4-dihydroxybenzoyl for the GCa benzoyl analog series.

In addition to the well-known carbamoyl, decarbamoyl, and sulfocarbamoyl derivatives, enhanced search efforts along with improved detection techniques and structural elucidation have led to the discovery of new groups of STX analogs in G. catenatum. In 2001, Negri et al. [15] detected some novel chromatographic "toxin-like" peaks. Further investigations revealed that these compounds, named GC1-3 toxins, were indeed new analogs. Extracts containing these analogs were purified for the first time by hydrophilic interaction liquid ion-chromatography (HILIC), and their structures were characterized by mass spectrometry (MS) and nuclear magnetic resonance (NMR) [16]. According to these authors, the GC3 analog is the para-hydroxybenzoyl derivative of dcSTX; GC1 and GC2 are C-11 sulfated variants of GC3 that form an enantiomeric pair depending on the stereochemical position of the sulfate group. 
Citation: Durán-Riveroll LM, Bernd Krock, Allan Cembella, Javier Peralta-Cruz, José J. Bustillos-Guzmán, et al. (2017) Characterization of Benzoyl Saxitoxin Analogs from the Toxigenic Marine Dinoflagellate Gymnodinium catenatum by Hydrophilic Interaction Liquid IonChromatography-Tandem Mass Spectrometry. Nat Prod Chem Res 5: 275. doi:10.4172/2329-6836.1000275

Page 3 of 14

Discovery of the benzoyl analogs added to the array of known toxins produced by $G$. catenatum and to the list of naturally occurring STX derivatives produced among toxigenic dinoflagellates. Thus far, the production of benzoyl analogs has been identified only in $G$. catenatum, but these toxins have been reported in different strains from diverse locations around the world (as mentioned in the review by [2]) and in bivalve mollusks that have fed upon natural blooms of this species. Extensive toxicity studies have not been conducted with all the analogs, mainly due to a lack of purified toxins, but their structures provide information to hypothesize about their potency. Some in vitro experiments with GC1/2 and GC3 have been performed on rat brain sodium channels, finding that these analogs bind strongly to the $\mathrm{Na}_{\mathrm{v}}$ but are somewhat less potent than STX. Nevertheless, the fact that these analogs possess a less polar benzoyl moiety raises the possibility that they have a greater ability than STX and other PSTs to cross epithelia. If this is the case, a higher selective absorption and also a greater potential for bioaccumulation and retention in some tissues, such as those of bivalve mollusks, and thus enhanced risk to human consumers, might be expected [17]. Only one theoretical study has been carried out via molecular docking. The study showed a theoretically high affinity of the GC toxins (GC1-6, GC1a-6a and GC1b-6b series of toxins) to the modelled $\mathrm{Na}_{\mathrm{v}}$ channel, although the results are not decisive due to the lack of correlation of the binding energies with the toxicity of the known analogs [18]. Despite the fact that these approaches are far from conclusive, they present the possibility that these toxins are relatively toxic in situ.

The suite of saxitoxin analogs produced by $G$. catenatum has been operationally grouped as "hydrophilic" toxins, which includes STX, gonyautoxins [GTXs], neosaxitoxin [NEO], decarbamoyl saxitoxin [dcSTX], decarbamoyl neosaxitoxin [dcNEO], decarbamoyl gonyautoxins [dcGTXs], and N-sulfocarbamoyl B and C toxins, versus so-called "hydrophobic" (e.g., benzoyl or GC) analogs [16,19-22] (Figure 1). Identification of benzoyl analogs has been hampered mainly by the lack of analytical standards [20,21,23], but probable structures for some analogs have been proposed based upon mass spectrometric analysis [20].

Benzoyl analogs have been detected in strains from Australia, China, Japan, Portugal, Uruguay, Spain, Korea [19], and Mexico [22], most of the time in even greater relative abundance (in mol\%) than the $\mathrm{N}$-sulfocarbamoyl (C) analogs, previously considered to be the most abundant analogs produced by this species. In some commercial bivalve species, GC toxins accounted for only a minor contribution to the toxin profile when contaminated by natural blooms, leading the hypothesis that these analogs are transformed into more potent ones, such as dcSTX. Biotransformation to decarbamoyl toxins would occur via the loss of the benzoyl side chain by carbamoylase enzyme activity, but this enzymatic conversion is uncommon among bivalves, and is typically restricted to a few clam species [23]. In the case of many other bivalves that lack the carbamoylase they may contain high amounts of untransformed GC toxins.

The aim of this current work was to obtain semi-purified fractions from an extract of $G$. catenatum strains from Mexican waters by preparative hydrophilic interaction liquid chromatography (HILIC) for confirmation of the presence and structures of benzoyl analogs. This approach successfully yielded 15 of 18 proposed naturally occurring benzoyl toxin derivatives.

\section{Materials and Methods}

\section{Isolates, culture conditions and harvest}

Three isolates of Gymnodinium catenatum, two from the Gulf of California and one from the Pacific coast of Mexico (Table 1), were cultured from water samples collected from natural populations. Isolates were grown in GSe medium [24] supplemented with earthworm soil extract in $19 \mathrm{~L}$ carboys, $4 \mathrm{~L}$ Erlenmeyer flasks and $3.8 \mathrm{~L}$ PET containers with seawater (salinity $33 \pm 1$ ) from Ensenada de La Paz, Baja California Sur, Mexico. Culture medium was prepared with chemically sterilized seawater $\left(17 \mathrm{mg} \mathrm{L}^{-1} \mathrm{Ca}(\mathrm{ClO})_{2}, 90 \%\right.$, standard commercial preparation). Nutrients were autoclaved at $121{ }^{\circ} \mathrm{C}$ for 15 minutes, and vitamins were filter-sterilized and added afterwards. Cultures were maintained at $24 \pm 1{ }^{\circ} \mathrm{C}$ on a $12: 12 \mathrm{~h}$ light:dark regime under $150 \mu \mathrm{mol} \mathrm{m} \mathrm{s}^{-2} \mathrm{~s}^{-1}$ illumination from cool-white fluorescent lights in a temperature-controlled growth room.

\begin{tabular}{|c|c|c|}
\hline Isolate (code) & Place and year of isolation & Isolated by \\
\hline GCCV-7 & $\begin{array}{l}\text { Bahía Concepción, B.C.S. } 2000\left(26^{\circ} 40^{\prime} \mathrm{N} \text { and } 111^{\circ} 50^{\prime}\right. \\
\text { W) }\end{array}$ & C. Band-Schmidt CODIMAR \\
\hline BAPAZ-5 & $\begin{array}{l}\text { Bahía de La Paz, B.C.S., } 2007 \\
\left(24^{\circ} 27^{\prime} \mathrm{N} \text { and } 110^{\circ} 30^{\prime} \mathrm{W}\right)\end{array}$ & C. Band-Schmidt Centro Interdisciplinario de Ciencias Marinas-IPN \\
\hline $62 \mathrm{~L}$ & $\begin{array}{l}\text { Lázaro Cárdenas, Michoacán, } 2005\left(17^{\circ} 58^{\prime} \mathrm{N} \text { and } 102^{\circ}\right. \\
\left.05^{\prime} \mathrm{W}\right)\end{array}$ & $\begin{array}{l}\text { M. C. Rodríguez-Palacio } \\
\text { Universidad Autónoma Metropolitana }\end{array}$ \\
\hline
\end{tabular}

Table 1: Gymnodinium catenatum isolates from different locations on the Mexican Pacific coast.

The cell biomass of a total of $300 \mathrm{~L}$ culture of the three isolates of $G$. catenatum was harvested and pooled. Individual cultures were harvested approximately every 15 days upon a $20 \mu \mathrm{m}$ nylon mesh. Cell suspension was centrifuged (Solbat, Model J-12, Aparatos Científicos, Mexico City) at room temperature for 15 minutes and at $1500 \mathrm{x}$ g. The pellet biomass was stored at $-20^{\circ} \mathrm{C}$ until toxin extraction.

\section{Toxin extraction}

The combined biomass was thawed and divided into 7 centrifuge tubes. Four $\mathrm{mL}$ of $0.17 \mathrm{M}$ acetic acid (ACS Vetec SIGMA, HPLC grade) were added to each tube. Tubes were ultrasonicated in an ultrasound bath (Cole Parmer 8891, Vernon Hills, USA) for 10 minutes and the cell biomass was re-frozen. After $24 \mathrm{~h}$, biomass was again thawed and ultrasonicated for another 10 minutes. Complete cell disruption was verified microscopically. Tubes were centrifuged for 15 minutes at 1500 
Citation: Durán-Riveroll LM, Bernd Krock, Allan Cembella, Javier Peralta-Cruz, José J. Bustillos-Guzmán, et al. (2017) Characterization of Benzoyl Saxitoxin Analogs from the Toxigenic Marine Dinoflagellate Gymnodinium catenatum by Hydrophilic Interaction Liquid IonChromatography-Tandem Mass Spectrometry. Nat Prod Chem Res 5: 275. doi:10.4172/2329-6836.1000275

Page 4 of 14

$\times g$ at room temperature. The supernatants were combined and then lyophilized.

\section{Fractionation by reverse-phase column chromatography}

Lyophilized crude extract was suspended in $13 \mathrm{~mL}$ of deionized distilled water and filtered through a syringe-mounted glass fiber filter (Whatman GFF, $0.47 \mu \mathrm{m}, 25 \mathrm{~mm}$ ). A chromatographic glass column (70 $\mathrm{cm}$ height $\times 4.5 \mathrm{~cm}$ i.d.) packed with $100 \mathrm{~g} \mathrm{C}-18$ silica gel (Bulk C-18 Flash, FCO140100-0, Agela Technologies, USA) was used for the first fractionation. Three eluents yielded three $1 \mathrm{~L}$ fractions: Fraction 1 (F1): deionized distilled water; F2: $20 \% \mathrm{v} / \mathrm{v} \mathrm{MeOH}$ (ACS Vetec SIGMA, HPLC grade); and F3: $100 \% \mathrm{MeOH}$. The $\mathrm{MeOH}$ was removed by rotary evaporation at $40{ }^{\circ} \mathrm{C}(\mathrm{F} 2$ and $\mathrm{F} 3)$ and the aqueous residue was lyophilized (F1 and F2).

\section{HILIC-MS/MS analysis}

Reagents for fractionation and HILIC-MS/MS analysis were purchased from Merck (Darmstadt, Germany). Mass spectral experiments to detect GC analogs were performed on a triple quadrupole mass spectrometer (API 4000 QTrap, AB Sciex, Darmstadt, Germany) equipped with a Turbo Ion Spray interface, coupled to a liquid chromatograph (model 1100, Agilent, Waldbronn, Germany). The liquid chromatograph included a solvent reservoir, inline degasser (G1379A), binary pump (G1311A), refrigerated autosampler (G1329A/G1330B) and temperature-controlled column oven (G1316A). Mass spectrometric analyses for GC analogs were carried out by addition of GC-toxin transitions (Table 2) to the method of Diener [25]. The column $(150 \times 4.6 \mathrm{~mm})$ packed with $5 \mu \mathrm{m}$ ZICHILIC stationary phase (Merck, Darmstadt, Germany) was maintained at $35^{\circ} \mathrm{C}$. In summary, the following operating parameters were applied at a flow rate of $0.7 \mathrm{~mL} \mathrm{~min}^{-1}$ : gradient elution was performed with eluent A ( $2 \mathrm{mM}$ formic acid and $5 \mathrm{mM}$ ammonium formate in acetonitrile in water $(80: 20 \mathrm{v} / \mathrm{v}))$ and eluent $\mathrm{B}(10 \mathrm{mM}$ formic acid and $10 \mathrm{mM}$ ammonium formate in water). Five $\mu \mathrm{L}$ of sample were injected and gradient elution for HILIC with MS detection was carried out as presented in Table 3.
Selected-reaction monitoring (SRM) experiments were conducted in positive-ion mode based on transitions listed in Table 2. Dwell times of 100-200 ms were used for each transition. The source parameters were: curtain gas $(30 \mathrm{psi})$, temperature $\left(650^{\circ} \mathrm{C}\right)$, ion spray voltage $(5000 \mathrm{~V})$, gas 1 and 2 (70 psi), interface heater (on), collision gas (high), declustering potential $(66 \mathrm{~V})$, entrance potential $(10 \mathrm{~V})$, collision energy $(30 \mathrm{~V})$, and collision cell exit potential $(12 \mathrm{~V})$.

\section{MS/MS guided fractionation}

Fraction $2(20 \% \mathrm{MeOH})$ and $3(100 \% \mathrm{MeOH})$ were further refractionated by HILIC chromatography guided by posterior MS/MS. Preparative work was performed on a Knauer chromatograph (Berlin, Germany), equipped with a $10 \mathrm{~mL}$ pump (Knauer $10 \mathrm{~mL}$ Nr. 43680), exchange valve (Smartline Valve Drive Nr. 99158), degasser (Smartline Manager 5000) and mixing chamber (Dynamic Mixing Chamber Nr. 102055). The same ZIC-HILIC stationary phase analytical column as previously described was loaded with consecutive $50 \mu \mathrm{L}$ injections. The column was operated at ambient temperature $\left(\sim 20^{\circ} \mathrm{C}\right)$, with otherwise identical parameters as in the previous analyses. The flow rate was 0.7 $\mathrm{mL} \mathrm{min}^{-1}$ for a total run time of 45 minutes.

Fractions were collected with a Gilson fraction collector (model 202150G5001, Villeurs-le-Bel, France). Each collected fraction was lyophilized and further analyzed by HILIC-MS/MS to determine toxin composition in order to continue stepwise preparative fractionation.

\section{${ }^{1} \mathrm{H}-\mathrm{NMR}$ spectroscopy}

${ }^{1} \mathrm{H}$-NMR experiments were performed at $25{ }^{\circ} \mathrm{C}$ in a Varian 500 spectrometer (Varian, Palo Alto, California) with 50 transients for each experiment, according to standard Varian ${ }^{1} \mathrm{H}$ sequence pulses. Exchanged $\mathrm{MeOH}$ intense signal was suppressed by presaturation at $4.54 \mathrm{ppm}$. The Free Induction Decays (FIDs) obtained were processed with MestReNOVA software (MestreLab, Spain).

\begin{tabular}{|c|c|c|c|c|c|}
\hline Analog & Lateral Chain & N1 & C-11 SO4 & MW & Ion precursor>fragments \\
\hline STX & \multirow{6}{*}{ CO- $\mathrm{NH}_{2}$ carbamoyl } & $\mathrm{H}$ & - & 299 & $\begin{array}{l}300>282 \\
300>204\end{array}$ \\
\hline NEO & & $\mathrm{OH}$ & - & 315 & $\begin{array}{l}316>298 \\
316>196\end{array}$ \\
\hline GTX1 & & $\mathrm{OH}$ & $\alpha$ & 411 & $\begin{array}{l}412>332 \\
412>314\end{array}$ \\
\hline GTX4 & & $\mathrm{OH}$ & $\beta$ & 411 & $\begin{array}{l}412>332 \\
412>314\end{array}$ \\
\hline GTX2 & & $\mathrm{H}$ & $\alpha$ & 395 & $\begin{array}{l}396>316 \\
396>298\end{array}$ \\
\hline GTX3 & & $\mathrm{H}$ & $\beta$ & 395 & $\begin{array}{l}396>316 \\
396>298\end{array}$ \\
\hline C1 & $\begin{array}{l}\mathrm{CO}-\mathrm{NH}-\mathrm{SO}_{3} \\
\mathrm{~N} \text {-sulfo-carbamoyl }\end{array}$ & $\mathrm{H}$ & $\alpha$ & 475 & $\begin{array}{l}396>316 \\
396>298\end{array}$ \\
\hline
\end{tabular}


Citation: Durán-Riveroll LM, Bernd Krock, Allan Cembella, Javier Peralta-Cruz, José J. Bustillos-Guzmán, et al. (2017) Characterization of Benzoyl Saxitoxin Analogs from the Toxigenic Marine Dinoflagellate Gymnodinium catenatum by Hydrophilic Interaction Liquid IonChromatography-Tandem Mass Spectrometry. Nat Prod Chem Res 5: 275. doi:10.4172/2329-6836.1000275

Page 5 of 14

\begin{tabular}{|c|c|c|c|c|c|}
\hline $\mathrm{C} 2$ & & $\mathrm{H}$ & $\beta$ & 475 & $\begin{array}{l}396>316 \\
396>298\end{array}$ \\
\hline C3 & & $\mathrm{OH}$ & $\alpha$ & 491 & $\begin{array}{l}412>332 \\
412>314\end{array}$ \\
\hline C4 & & $\mathrm{OH}$ & $\beta$ & 491 & $\begin{array}{l}412>332 \\
412>314\end{array}$ \\
\hline B1 & & $\mathrm{H}$ & - & 379 & $\begin{array}{l}380>300 \\
380>282\end{array}$ \\
\hline B2 & & $\mathrm{OH}$ & - & 395 & $\begin{array}{l}396>316 \\
396>298\end{array}$ \\
\hline dcSTX & \multirow{6}{*}{ H decarbamoyl } & $\mathrm{H}$ & - & 256 & $\begin{array}{l}257>196 \\
257>156\end{array}$ \\
\hline dcNEO & & $\mathrm{OH}$ & - & 272 & $273>255$ \\
\hline dcGTX1 & & $\mathrm{OH}$ & $\alpha$ & 368 & $369>289$ \\
\hline dcGTX4 & & $\mathrm{OH}$ & $\beta$ & 368 & $369>289$ \\
\hline dcGTX2 & & $\mathrm{H}$ & $\alpha$ & 352 & $353>273$ \\
\hline dcGTX3 & & $\mathrm{H}$ & $\beta$ & 352 & $353>273$ \\
\hline GC1 & \multirow{6}{*}{ p-hydroxy-benzoyl } & $\mathrm{H}$ & $\alpha$ & 472 & $473>455,393,375$ \\
\hline GC2 & & $\mathrm{H}$ & $\beta$ & 472 & $473>455,393,375$ \\
\hline GC3 & & $\mathrm{H}$ & - & 376 & $377>359,257$ \\
\hline GC4 & & $\mathrm{OH}$ & $\alpha$ & 488 & $489>471,409,391$ \\
\hline GC5 & & $\mathrm{OH}$ & $\beta$ & 488 & $489>471,409,391$ \\
\hline GC6 & & $\mathrm{OH}$ & - & 392 & $393>375,273$ \\
\hline GC1a & \multirow{6}{*}{ di-hydroxy-benzoyl } & $\mathrm{H}$ & $\alpha$ & 488 & $489>471,409$ \\
\hline GC2a & & $\mathrm{H}$ & $\beta$ & 488 & $489>471,409$ \\
\hline GC3a & & $\mathrm{H}$ & - & 392 & $393>375,257$ \\
\hline GC4a & & $\mathrm{OH}$ & $\alpha$ & 504 & $505>487,425$ \\
\hline GC5a & & $\mathrm{OH}$ & $\beta$ & 504 & $505>487,425$ \\
\hline GC6a & & $\mathrm{OH}$ & - & 408 & $409>391,273$ \\
\hline GC1b & \multirow{6}{*}{ sulfo-benzoyl } & $\mathrm{H}$ & $\alpha$ & 552 & $553>393$ \\
\hline $\mathrm{GC} 2 \mathrm{~b}$ & & $\mathrm{H}$ & $\beta$ & 552 & $553>393$ \\
\hline GC3b & & $\mathrm{H}$ & - & 456 & $457>377$ \\
\hline GC4b & & $\mathrm{OH}$ & $\alpha$ & 568 & $569>409$ \\
\hline GC5b & & $\mathrm{OH}$ & $\beta$ & 568 & $569>409$ \\
\hline GC6b & & $\mathrm{OH}$ & - & 472 & $473>393$ \\
\hline
\end{tabular}

Table 2: Lateral chain, functional group at nitrogen 1 (N1), position of sulfate group at carbon 11 (C-11), molecular weight (MW) and mass transitions $(\mathrm{m} / \mathrm{z})$ of the PSTs analyzed. 
Citation: Durán-Riveroll LM, Bernd Krock, Allan Cembella, Javier Peralta-Cruz, José J. Bustillos-Guzmán, et al. (2017) Characterization of Benzoyl Saxitoxin Analogs from the Toxigenic Marine Dinoflagellate Gymnodinium catenatum by Hydrophilic Interaction Liquid IonChromatography-Tandem Mass Spectrometry. Nat Prod Chem Res 5: 275. doi:10.4172/2329-6836.1000275

Page 6 of 14

\section{Results}

We identified 15 different GC analogs in the methanolic fractions isolated from $G$. catenatum cells, although structural confirmation of all of them was not possible by mass spectrometry alone. To be consistent with previous research $[25,26]$, we considered that analogs with the sulfate group located at $\mathrm{C}-11$ in $\alpha$-position were the first to elute, and those with the sulfate group in $\beta$-position eluted later, as shown in the tables, but we did not confirm this elution pattern.

\begin{tabular}{|c|c|c|}
\hline Time (minutes) & \% eluent A & \% eluent B \\
\hline 0 & 80 & 20 \\
\hline 5 & 65 & 35 \\
\hline 20 & 60 & 40 \\
\hline 24 & 55 & 45 \\
\hline 25 & 55 & 45 \\
\hline
\end{tabular}

Table 3: Gradient program for HILIC-MS/MS.

\section{Initial fractionation and preparative chromatography}

\begin{tabular}{|l|c|c|}
\hline Fraction & Weight (g) \\
\hline Fraction $1\left(\mathrm{~F} 1, \mathrm{H}_{2} \mathrm{O}\right)$ & 1.185 \\
\hline Fraction $2(\mathrm{~F} 2,20 \% \mathrm{MeOH})$ & 0.088 & 53.2 \\
\hline Fraction 3 (F3, $100 \% \mathrm{MeOH})$ & 0.017 \\
\hline Total yield (three fractions) & 0.0 \\
\hline
\end{tabular}

Table 4: Fraction weight and yield.

\begin{tabular}{|c|c|c|}
\hline GC Toxin & $m / z$ & RT (min) \\
\hline GC1 & \multirow[t]{2}{*}{473} & 7.05 \\
\hline GC2 & & 10.63 \\
\hline GC4 & \multirow[t]{4}{*}{489} & 5.96 \\
\hline GC5 & & 8.82 \\
\hline GC1a & & 10.50 \\
\hline $\mathrm{GC} 2 \mathrm{a}$ & & 14.04 \\
\hline GC4a & \multirow[t]{2}{*}{505} & 6.40 \\
\hline GC5a & & 8.28 \\
\hline GC1b & \multirow[t]{2}{*}{553} & 7.02 \\
\hline $\mathrm{GC} 2 \mathrm{~b}$ & & 10.13 \\
\hline GC4b & \multirow[t]{2}{*}{569} & 8.85 \\
\hline GC5b & & 13.96 \\
\hline
\end{tabular}

Table 5: GC toxins identified in F2 (20\% MeOH) by HILIC-MS/MS analysis.

In this work, F1 (aqueous) was not further analyzed because it was known to contain all the so-called "hydrophilic" STX analogs, but was not expected to include the target benzoyl derivatives. This justified the focus on analysis of toxins in fractions F2 and F3, which presumably contained the benzoyl STX analogs (Figure 2). 
Citation: Durán-Riveroll LM, Bernd Krock, Allan Cembella, Javier Peralta-Cruz, José J. Bustillos-Guzmán, et al. (2017) Characterization of Benzoyl Saxitoxin Analogs from the Toxigenic Marine Dinoflagellate Gymnodinium catenatum by Hydrophilic Interaction Liquid IonChromatography-Tandem Mass Spectrometry. Nat Prod Chem Res 5: 275. doi:10.4172/2329-6836.1000275

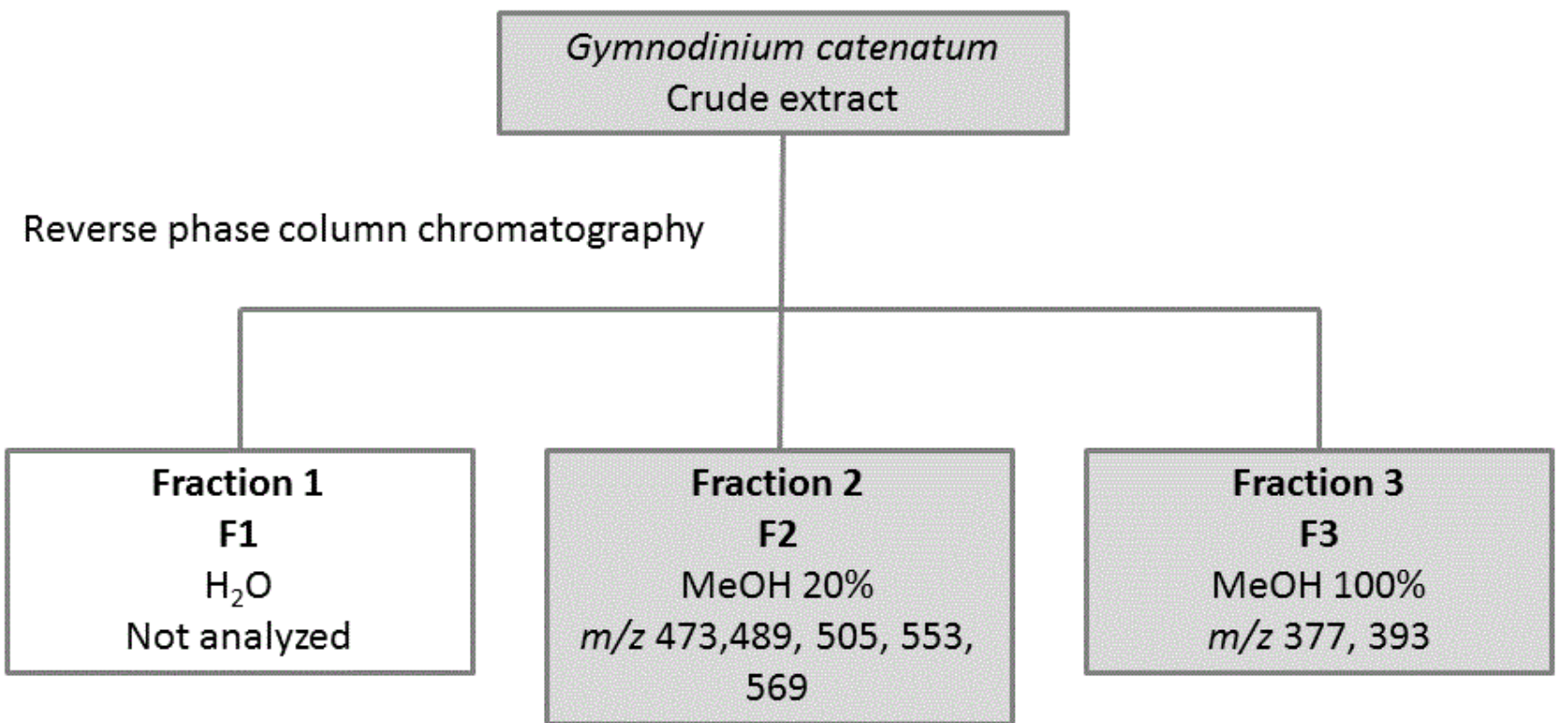

\section{HILIC-MS/MS of chromatographic fractions and preparative HILIC chromatography}

HILIC-MS/MS analysis of F2 yielded compounds with $\mathrm{m} / \mathrm{z} 473,489$, 505, 553 and 569 (Table 5 and Figure 3).

\section{Fraction $2(20 \% \mathrm{MeOH})$}

Twelve GC toxins were identified from F2 $(20 \% \mathrm{MeOH})$, including the N1-OH analogs GC4/5, GC4a/5a and GC4b/5b. The preliminary

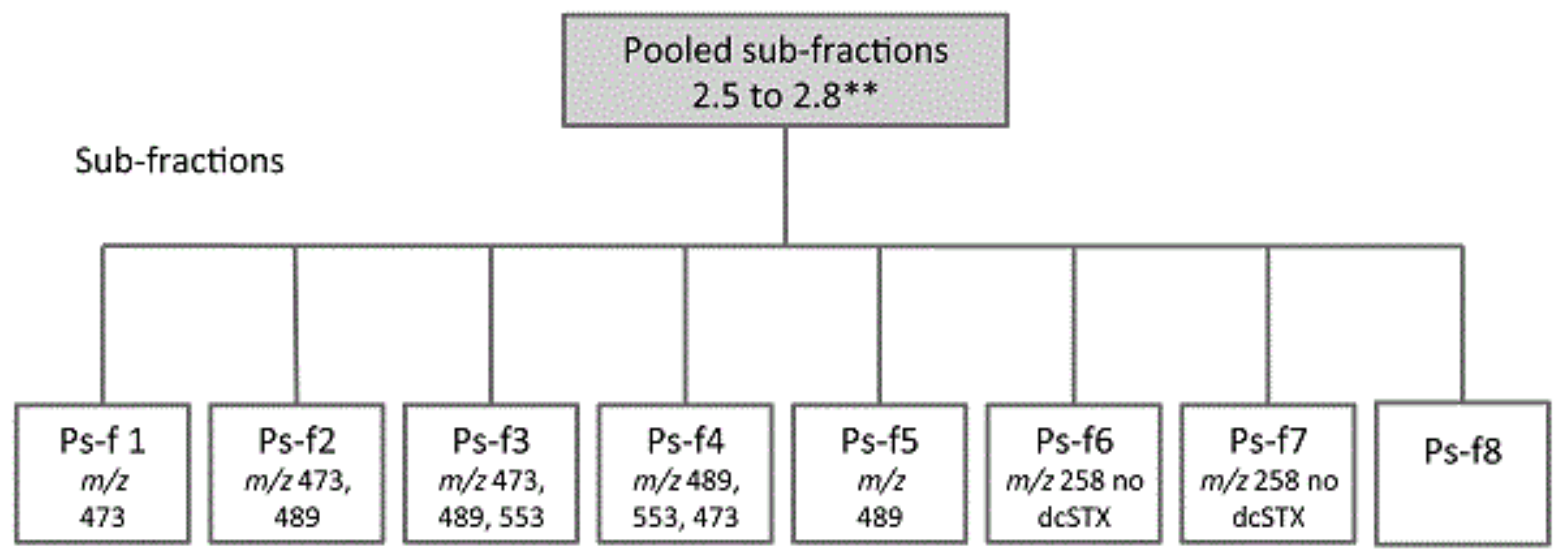

Figure 5: Fractionation of pooled sub-fractions (Ps-f) (from Figure 4) by preparative HILIC chromatography. The $\mathrm{m} / \mathrm{z} 553$ was not detected in previous fractions, probably due to very low concentration. All GC analogs corresponding $\mathrm{m} / \mathrm{z}$ values found by HILIC-MS/MS in each fraction are indicated in the fractionation scheme. Other $\mathrm{m} / \mathrm{z}$ values (such as for $\mathrm{C}$ toxins) are not reported in this scheme, but were found in all pooled sub-fractions with the exception of Ps-f7 and 8. 
Citation: Durán-Riveroll LM, Bernd Krock, Allan Cembella, Javier Peralta-Cruz, José J. Bustillos-Guzmán, et al. (2017) Characterization of Benzoyl Saxitoxin Analogs from the Toxigenic Marine Dinoflagellate Gymnodinium catenatum by Hydrophilic Interaction Liquid IonChromatography-Tandem Mass Spectrometry. Nat Prod Chem Res 5: 275. doi:10.4172/2329-6836.1000275

Page 8 of 14

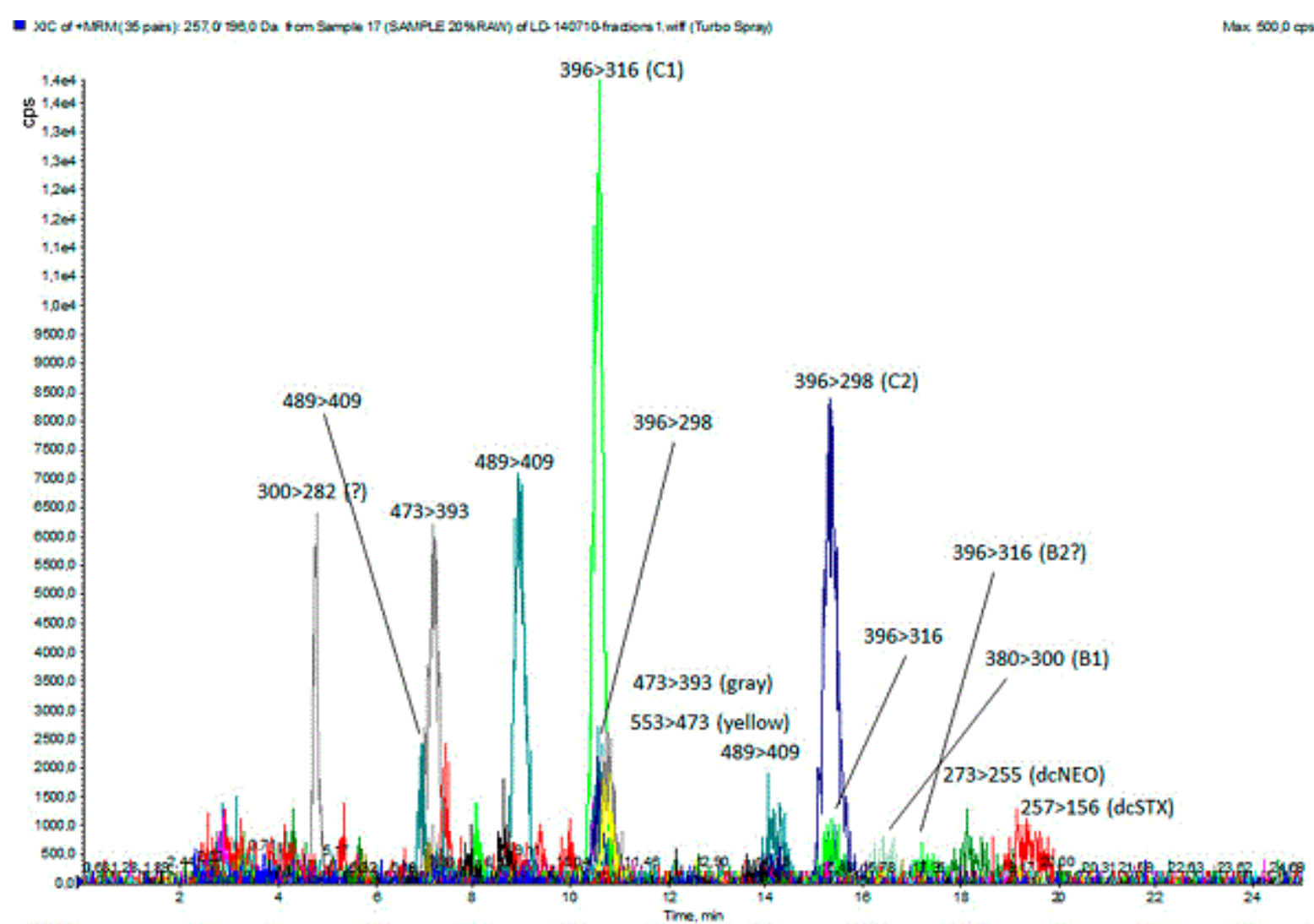

Figure 3: HILIC-MS/MS chromatogram of crude F2 $(20 \% \mathrm{MeOH})$ with selected reaction monitoring (SRM) in positive ion mode. The detected $\mathrm{m} / \mathrm{z}$ corresponding to specific toxins are indicated. Not all the $\mathrm{m} / \mathrm{z}$ values reported in Table 2 are indicated in this chromatogram because some analogs were only detectable after further purification.

Sub-fractionation (12 increments) of F2 in the first step provided relatively higher purity of component(s) with $\mathrm{m} / \mathrm{z} 393$, corresponding to GC3a, but only in sub-fraction F2.2. Sub-fractions 2.5 to 2.8 of F2 contained compounds with $\mathrm{m} / \mathrm{z} 473$ and 489 , corresponding to toxins GC1/2 and/or GC6b, and GC4/5 and/or GC1a/2a, respectively. Accordingly, these sub-fractions were pooled and refractionated (Figures 4 and 5).

The main compound found in sub-fraction F2.9 exhibited $\mathrm{m} / \mathrm{z} 489$, corresponding to GC4/5 and GC1a/2a, but this component was mixed in the sub-fraction with the characteristic $\mathrm{m} / z$ of $\mathrm{C} 1 / 2$ toxins. A subsequent fractionation showed only $\mathrm{m} / z$ of $\mathrm{C}$ toxins, probably because the compound with $\mathrm{m} / \mathrm{z} 489$ was separated into several subfractions and was not detectable anymore. Sub-fractions 2.10, 2.11, 2.12 and 2.13 also yielded only $\mathrm{m} / \mathrm{z}$ corresponding to $\mathrm{C}$ toxins, and were therefore discarded. The pooled sub-fractions (Ps-f) F2.5 to 2.8 (Figure 5) contained $\mathrm{C} 1 / 2$ toxins co-eluting with compounds of $\mathrm{m} / \mathrm{z}$ 473,489 and 533 that were not detectable in previous fractions probably due to their very low concentration.

\section{Fraction 3 (100\% MeOH)}

In $\mathrm{F} 3(100 \% \mathrm{MeOH})$, three other GC analogs, including GC3, were detected, but these were not present in F2. In F3 one peak with the transition $\mathrm{m} / \mathrm{z} 377>257$ and two peaks at transition $393>273$ were detected (Table 6 and Figures 6 and 7); these $m / z$ transitions also correspond to benzoyl analogs. Sub-fractionation in the initial preparative chromatography yielded putative GC3 toxin $(\mathrm{m} / \mathrm{z}$ $377>257$ ) in sub-fraction F3.3. Refractionation was successful in obtaining this GC3 toxin with higher purity, but given that the GC3 structure has been previously confirmed by ${ }^{1} \mathrm{H}-\mathrm{NMR}$ [16] this component was not subjected to further confirmation in our study. The two low abundant peaks at transition $\mathrm{m} / \mathrm{z} 393>273$ are consistent with the molecular masses of GC6 and GC3a. Significantly, at the retention time of the first peak (2.3 minutes) there is a peak at the transition $273>255$. This transition is typical for dcNEO, but this analog elutes far later and thus cannot be responsible for this signal. On the other hand, the fragment of the transition of $\mathrm{m} / \mathrm{z}$ is formed by the loss of the hydroxybenzoyl moiety from GC6 and the formed $m / z 273$ fragment can suffer a further water loss to yield $\mathrm{m} / \mathrm{z} 255$.

This fragmentation pattern can only be observed for GC6 and not for GC3a, because GC3a is a dihydroxybenzoyl compound and thus generates a different primary fragment. Taken together, this evidence allows us to postulate that the first compound (at 2.3 minutes) at transition $\mathrm{m} / \mathrm{z} 393>273$ is GC6 and the later eluting analog (at 3.7 minutes) is GC3a. This is also consistent with the expected retention behavior of both compounds with the more polar dihydroxy compound GC3a having stronger interactions with the polar HILIC phase and accordingly eluting later than the less polar monohydroxy GC6. 
Citation: Durán-Riveroll LM, Bernd Krock, Allan Cembella, Javier Peralta-Cruz, José J. Bustillos-Guzmán, et al. (2017) Characterization of Benzoyl Saxitoxin Analogs from the Toxigenic Marine Dinoflagellate Gymnodinium catenatum by Hydrophilic Interaction Liquid IonChromatography-Tandem Mass Spectrometry. Nat Prod Chem Res 5: 275. doi:10.4172/2329-6836.1000275

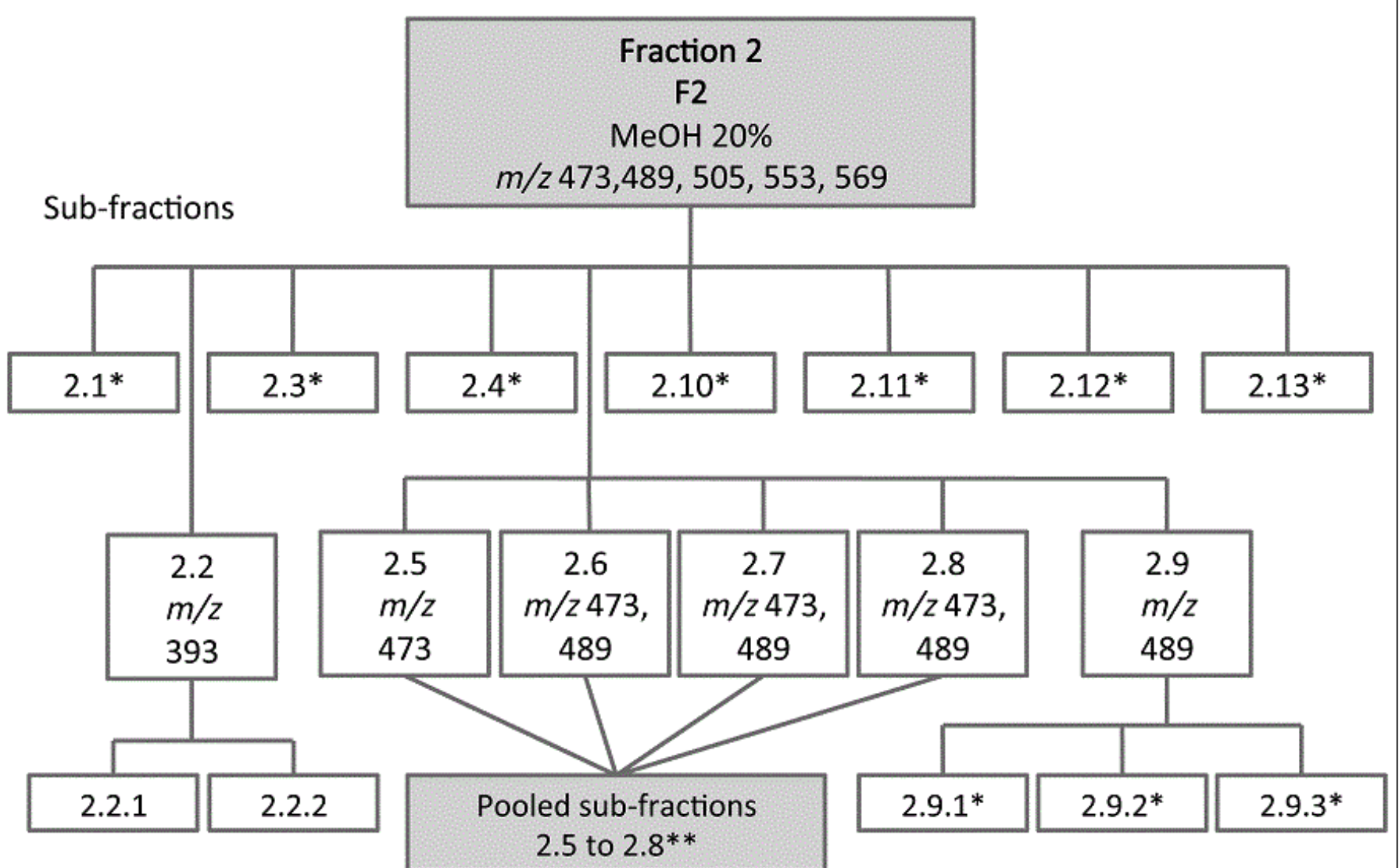

Figure 4: Sub-fractionation of Gymnodinium catenatum F2 by preparative HILIC chromatography. The $m / z$ values corresponding to GC analogs found by HILIC-MS/MS in each fraction are indicated. Fraction 2.9 also showed $\mathrm{m} / \mathrm{z}$ corresponding to $\mathrm{C}$ toxins (not shown). Fractions marked ${ }^{*}$ were discarded. ${ }^{* *}$ continues in Figure 5.

\begin{tabular}{|c|c|c|}
\hline GC Toxin & $\mathbf{m} / \mathbf{z}$ & RT (min) \\
\hline GC3 & 377 & 2.84 \\
\hline GC6 or & 393 & 2.33 \\
\hline GC3a & - & 2.27 \\
\hline
\end{tabular}

Table 6: GC toxins identified in F3 (100\% MeOH) by HILIC-MS/MS analysis.

\section{${ }^{1}$ H-NMR spectroscopy}

In order to discriminate among GC4/5 (N1-OH hydroxybenzoyl analogs) and GC1a/2a (di-hydroxybenzoyl) analogs, we performed ${ }^{1} \mathrm{H}$ NMR spectroscopy on fractions 3 and 4 of the Ps-f (Ps-f3 and Ps-f4, Figure 5). Results from these analyses showed the nitrogen base coupled protons from 3.01 to $4.23 \mathrm{ppm}$ in the aliphatic regions. This arrangement belongs to the six membered guanidine and pyrrolidine ring of the proposed tricyclic base structure (Figure 1). Protons of the aliphatic cyclopentyl ring were observed from 1.91 to $2.80 \mathrm{ppm}$. The protons of the aromatic region of the spectrum in Ps- $\mathrm{f} 3$ displayed the typical symmetrical pattern AA'BB', centered at $7.9 \mathrm{ppm}(\mathrm{J}=6.82 \mathrm{~Hz})$, corresponding to the para-substituted hydroxy-benzoyl ring (1benzoyl-4-hydroxy derivative) [27] (Figure 8). According to the $m / z$ in 
Citation: Durán-Riveroll LM, Bernd Krock, Allan Cembella, Javier Peralta-Cruz, José J. Bustillos-Guzmán, et al. (2017) Characterization of Benzoyl Saxitoxin Analogs from the Toxigenic Marine Dinoflagellate Gymnodinium catenatum by Hydrophilic Interaction Liquid IonChromatography-Tandem Mass Spectrometry. Nat Prod Chem Res 5: 275. doi:10.4172/2329-6836.1000275

Page 10 of 14

these sub-fractions, this pattern could only correspond to analogs GC4/5 ( $m / z$ 489), i.e., N1-OH hydroxybenzoyl analogs.

Di-hydroxylated benzoyl analogs, such as GC1a/2a, containing two hydroxyl moieties on the benzoyl ring, and/or GC4/5, containing one hydroxyl group on the benzoyl ring and a second hydroxyl on $\mathrm{N}-1$, both with $\mathrm{m} / \mathrm{z} 489$, were found in sub-fraction Ps-f4. The ${ }^{1} \mathrm{H}-\mathrm{NMR}$ spectrum of this sub-fraction showed the same signals for the six membered guanidine and pyrrolidine ring detailed above. However, this sub-fraction displayed an AMX pattern for protons H-2, H-5 and H-6, corresponding to a 3,4-dihydroxy-benzoyl derivative GCla/2a $(\delta \mathrm{HA}=8.48 \mathrm{ppm}, \mathrm{d}, \mathrm{J}=2 \mathrm{~Hz}, \delta \mathrm{HB}=8.29 \mathrm{ppm}, \mathrm{d}, \mathrm{J}=2 \mathrm{~Hz} \delta \mathrm{HX}=7.82 \mathrm{ppm}$, dd, $\mathrm{J}=2 \mathrm{~Hz}$ ) mixed with the para-hydroxy-benzoyl derivative GC4/5 (Figure 9).

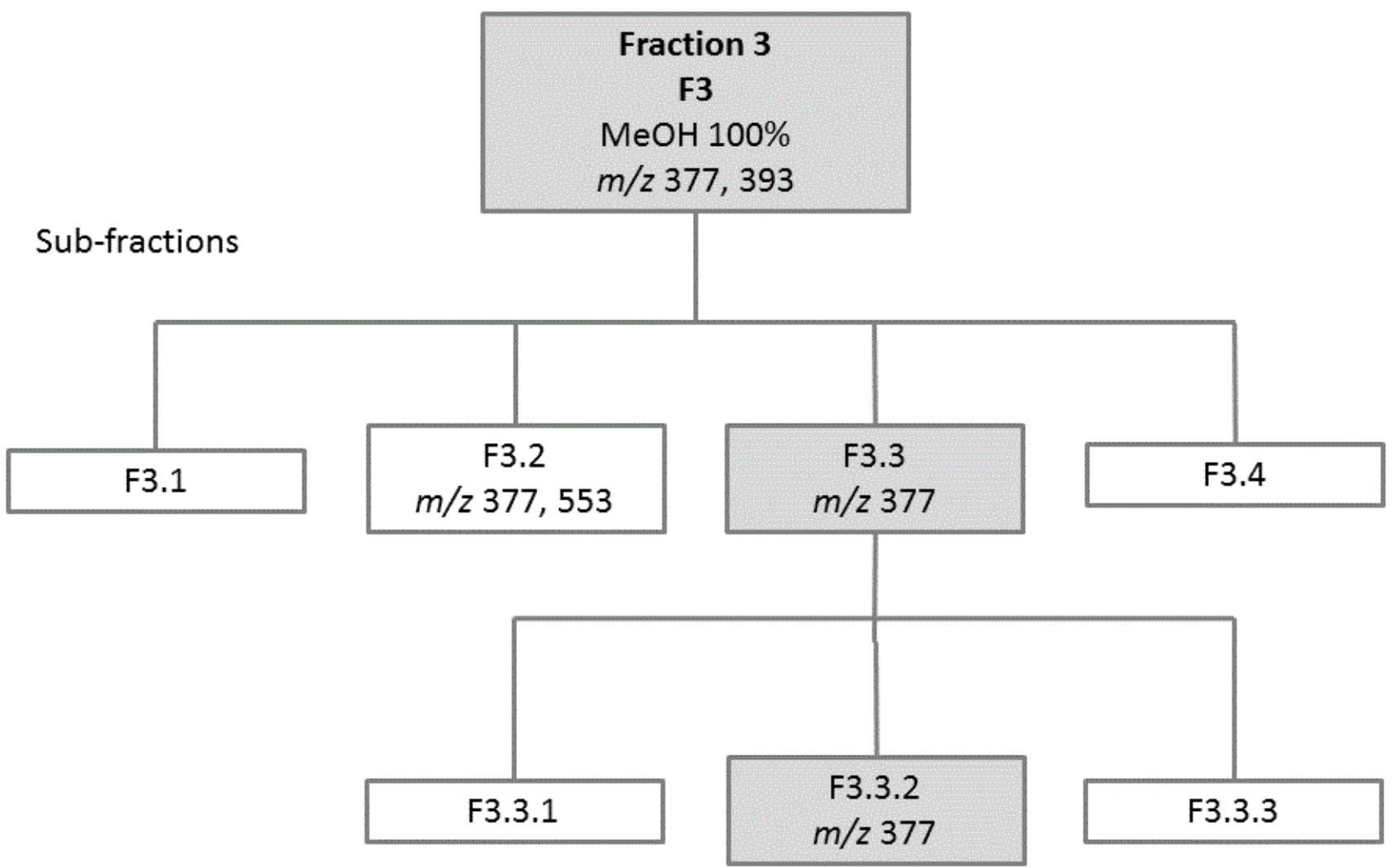

Figure 6: Sub-fractionation of Gymnodinium catenatum F3 by preparative HILIC chromatography. The $m / z$ values found by HILIC-MS/MS in each fraction are indicated here.

\section{Discussion}

\section{Polarity of GC toxins and chromatographic aspects of retention and identification of GC toxins}

The GC toxins have been commonly considered as "hydrophobic analogs" due to the presence of the benzoyl side chain, but this terminology is clearly inaccurate because the chromatographic behavior of the benzoyl analogs reveals that they are as hydrophilic as many so-called "hydrophilic analogs". A better grouping would be simply based upon structural consideration of their respective side chains, i.e., as carbamoyl, decarbamoyl, sulfocarbamoyl, or benzoyl analogs. The latter group can be further sub-divided into parahydroxybenzoyl, di-hydroxybenzoyl and sulfo-benzoyl analogs [20] (Figure 1).
Unequivocal identification of all mass-specific analogs in the fractions was not possible exclusively by mass spectrometry. One of the difficulties in determining the structures of the poorly characterized GC toxins by LC-MS/MS is that some analogs have the same mass-tocharge ratio $(m / z)$ (e.g., GC4, GC5, GCla, GC2a, all with $m / z 489$ ) (Table 2). These analogs contain the same substituent (hydroxyl or sulfate group, or both), but at different sites, e.g., hydroxyl group on $\mathrm{N}-1$ or on the benzoyl ring and sulfate groups on C-11 or on the benzoyl ring. Nevertheless, we considered that the molecules with the sulfate group in $\alpha$-position were the first to elute, as mentioned by Diener [25] and Dell'Aversano [26]. In such cases, structural identification must be supported by NMR, or at least by analysis of the molecular fragments obtained by tandem mass spectrometry, such as those reported by Vale [20]. 
Citation: Durán-Riveroll LM, Bernd Krock, Allan Cembella, Javier Peralta-Cruz, José J. Bustillos-Guzmán, et al. (2017) Characterization of Benzoyl Saxitoxin Analogs from the Toxigenic Marine Dinoflagellate Gymnodinium catenatum by Hydrophilic Interaction Liquid lonChromatography-Tandem Mass Spectrometry. Nat Prod Chem Res 5: 275. doi:10.4172/2329-6836.1000275

Page 11 of 14

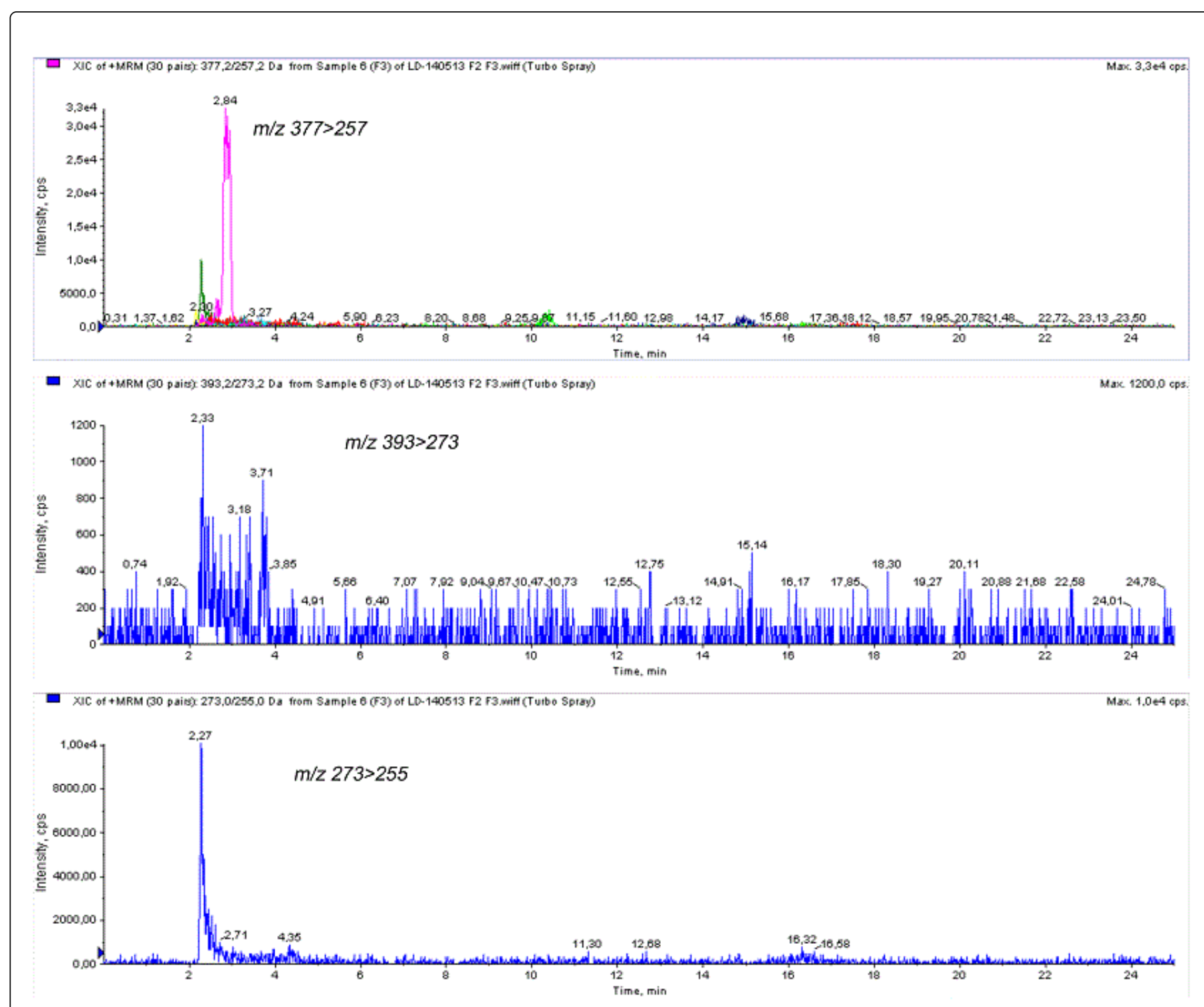

Figure 7: HILIC-MS/MS chromatogram of F3 $(100 \% \mathrm{MeOH})$ with selected reaction monitoring (SRM) in positive ion mode. The detected $m / z$ corresponding to benzoyl toxins are indicated.

\section{Fractionation}

Complete purification of the fraction components was not achieved because an analytical (rather than a semi-preparative) HILIC column was employed for the fractionation, requiring multiple $50 \mu \mathrm{L}$ injections at each step. Chromatographic system inconsistencies and thermal variation among multiple runs may have caused slight changes in the retention times, thereby hampering the generation of more purified fractions.

Furthermore, in our earlier work and in previous studies of GCtoxins in unfractionated matrices (e.g., Vale [20]), 2 g C-18 silica cartridges were used for clean-up, typically yielding a 2:1 ratio of solid phase: sample volume. Although it is difficult to compare the amount of target analytes for purification in various fractions, the fractionation scheme whereby a relatively high amount $(1.3 \mathrm{~g})$ of crude extract was applied to $100 \mathrm{~g}$ C-18 silica column may have caused less specific separation and even breakthrough of toxin components due to excessive loading.

Evidence of column retention inconsistencies is apparent from the chromatogram of F3 (Figure 7) that showed two ion masses, one corresponding to GC3 $(\mathrm{m} / z$ 377) and one corresponding to GC6 and/or GC3a $(\mathrm{m} / z$ 393), but after the first preparative fractionation, the latter peak was no longer detected. The GC3 analog has been previously reported by LC-FLD analysis of fractions obtained with $\mathrm{MeOH}$ concentrations $<100 \%[16,19-22,28]$, but most of this toxin is probably lost during the clean-up stage in the $100 \% \mathrm{MeOH}$ rinse after elution through the $\mathrm{C}-18$ solid-phase extraction cartridges.

Although it was not possible to obtain pure GC toxin analogs, the purity was high enough to allow confirmation of the di-hydroxylated 
Citation: Durán-Riveroll LM, Bernd Krock, Allan Cembella, Javier Peralta-Cruz, José J. Bustillos-Guzmán, et al. (2017) Characterization of Benzoyl Saxitoxin Analogs from the Toxigenic Marine Dinoflagellate Gymnodinium catenatum by Hydrophilic Interaction Liquid IonChromatography-Tandem Mass Spectrometry. Nat Prod Chem Res 5: 275. doi:10.4172/2329-6836.1000275

Page 12 of 14

benzoyl derivatives [29]. The chemical shifts and coupling constants from ${ }^{1} \mathrm{H}$-NMR, suggesting a 1-carboxy-3,4-dihydroxy substitution, leads to a putative corrected structure for the GCa series of analogs
(GC1a-GC6a), and provides grounds for rejection of the previous 3-5 dihydroxy-benzoyl moiety, as proposed by Vale [20].

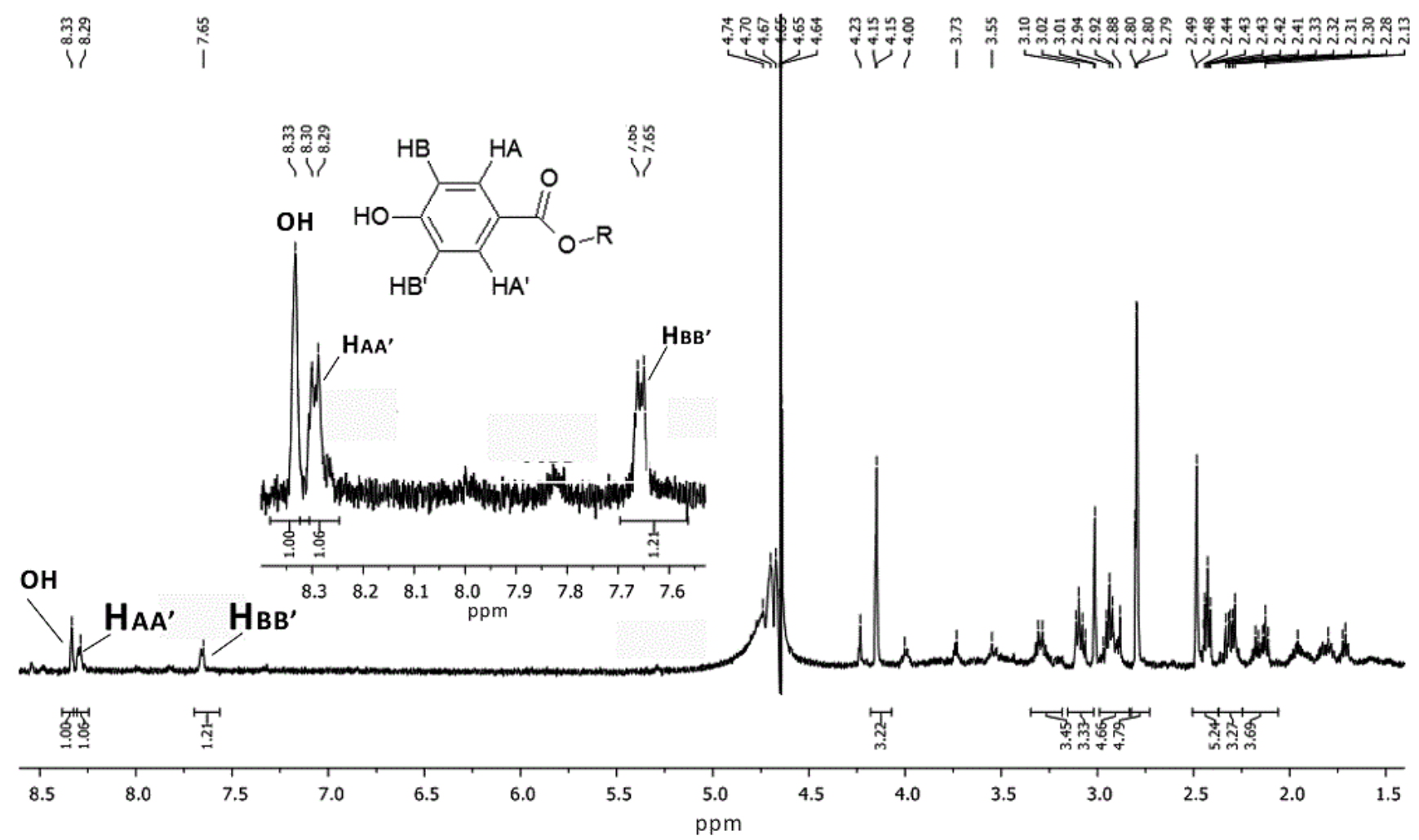

Figure 8: ${ }^{1} \mathrm{H}-\mathrm{NMR}\left(500 \mathrm{MHZ}, \mathrm{CD}_{3} \mathrm{OD}\right.$ with presaturation at $4.66 \mathrm{ppm}$ ) of the fraction Ps-f3 showing the aliphatic chain from 1.5 to 4.25 ppm; residuary hydroxyl group appears at $8.33 \mathrm{ppm}$ as a broad signal. The expanded aromatic region (inset) showed the characteristic AA'BB' part of 4-substituted hydroxy-esters.

\section{Conclusion}

These results confirm the presence of 15 GC analogs from among the 18 theoretical analogs previously reported from the dinoflagellate G. catenatum [20]. Combining HILIC LC-MS/MS with ${ }^{1} \mathrm{H}-\mathrm{NMR}$ analysis represents a significant advance over previous nonconfirmatory analysis by LC-FLD and LC-MS for the structural elucidation and confirmation of unknown and poorly characterized GC-toxins in various matrices. The lack of sufficient pure GC toxins for analytical calibration standards for liquid chromatography with either fluorescence or mass spectrometric detection and to perform specific toxicity tests (in vivo or in vitro) on purified toxins could be addressed by advanced preparative chromatography approaches. For example, the application of crude fractions to a preparative HILIC column would improve yield and reduce inconsistencies in fractionation due to consecutive multiple injections upon an analytical column.

Our study focused only on a few selected cultured strains from the Gulf of California and Pacific coast of Mexico, thereby highlighting the need for toxin diversity studies from other geographical locations. Application of HILIC-MS/MS provides the opportunity to explore genetic variation among populations of $G$. catenatum that include a GC-toxin component within their toxin profiles. Our current chromatographic approach coupled with tandem mass spectrometry and proton NMR spectral analysis of the GC-toxins contributes to the scarce structural information about these benzoyl analogs from $G$. catenatum. To our knowledge, this work represents the first confirmation and at least partial structural elucidation of $15 \mathrm{GC}$ analogs from this marine dinoflagellate. 
Citation: Durán-Riveroll LM, Bernd Krock, Allan Cembella, Javier Peralta-Cruz, José J. Bustillos-Guzmán, et al. (2017) Characterization of Benzoyl Saxitoxin Analogs from the Toxigenic Marine Dinoflagellate Gymnodinium catenatum by Hydrophilic Interaction Liquid IonChromatography-Tandem Mass Spectrometry. Nat Prod Chem Res 5: 275. doi:10.4172/2329-6836.1000275

Page 13 of 14

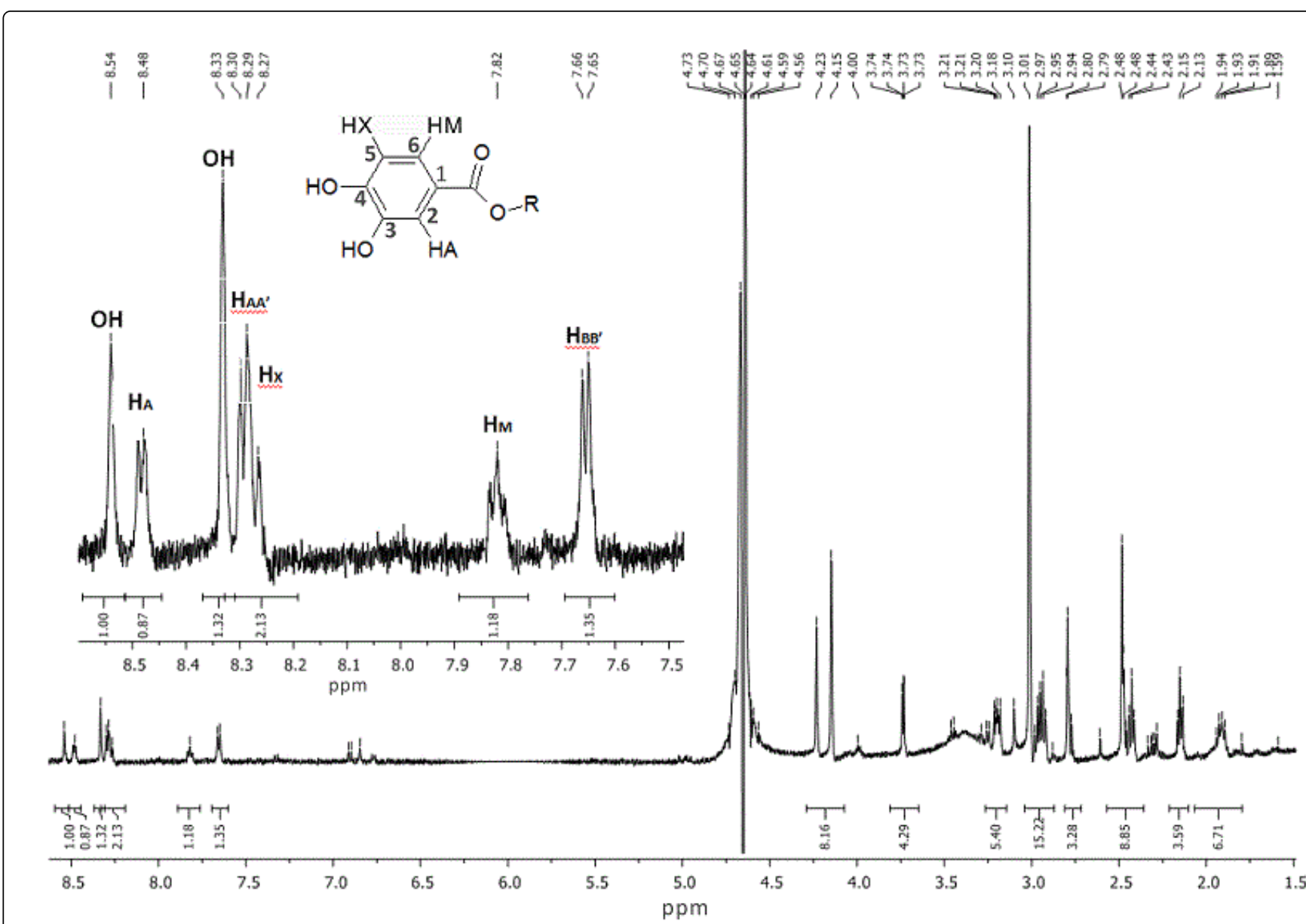

Figure 9: ${ }^{1} \mathrm{H}-\mathrm{NMR}$ (500 MHZ, $\mathrm{CD}_{3} \mathrm{OD}$ with presaturation at $4.66 \mathrm{ppm}$ ) of the fraction Ps- $\mathrm{f} 4$ showing the aliphatic chain from 1.5 to 4.25 ppm, broad signals at 8.54 and $8.33 \mathrm{ppm}$ were assigned to hydroxyl groups. The expanded aromatic region (inset) showed a mixture of 4 -substituted hydroxy-esters as an AA'BB' pattern. Substituted 3,4- dihydroxy-esters were observed as an AMX coupled system. The concentration in the sample was too low to obtain higher resolution, but some characteristics of the molecule are still visible.

\section{Acknowledgment}

We thank the German Academic Exchange Service (DAAD) for the research scholarship awarded to LMDR in Germany. LMDR was a recipient of a doctoral fellowship (CONACYT 65354; BEIFI-IPN); CJBS is an EDI and COFAA recipient. This work was partially financed by the Helmholtz-Gemeinschaft Deutscher Forschungszentren through the research program PACES of the Alfred Wegener InstitutHelmholtz Zentrum für Polar-und Meeresforschung, Germany, and Mexican sources (Project SIP 2016-1180, CYTED grant 214RT0482, and CIBNOR grant PC0.10 and PC0.11). The technical assistance of Annegret Müller at AWI is greatly appreciated. We thank Dr. Matthias Köck and Dr. Jan Tebben (AWI) for help in interpretation of the NMR spectra as presented. We thank CODIMAR for providing Gymnodinium catenatum strain GCCV-7 and M.C. Rodríguez Palacio, Universidad Autónoma Metropolitana, Mexico for providing the strain 62L. The founding sponsors had no role in the design of the study; in the collection, analyses, or interpretation of data; in the writing of the manuscript, and in the decision to publish the results. We dedicate this work to the memory of our co-author Dr. Javier Peralta Cruz, beloved friend, kind chemistry professor and unforgettable colleague, who died unexpectedly just after the completion of this work. We miss you and your many contributions.

\section{Author Contribution}

LMDR performed the experiments, analyzed the data and wrote the paper; BK and JPC conceived and designed the experiments, and analyzed the data; AC provided laboratory support and contributed to integration of the results and writing the paper; JBG reviewed the results; CBS contributed materials and reviewed the paper.

\section{Conflicts of Interest}

The authors declare no conflict of interest. The founding sponsors had no role in the design of the study; in the collection, analyses, or interpretation of data; in the writing of the manuscript, and in the decision to publish the results. 
Citation: Durán-Riveroll LM, Bernd Krock, Allan Cembella, Javier Peralta-Cruz, José J. Bustillos-Guzmán, et al. (2017) Characterization of Benzoyl Saxitoxin Analogs from the Toxigenic Marine Dinoflagellate Gymnodinium catenatum by Hydrophilic Interaction Liquid IonChromatography-Tandem Mass Spectrometry. Nat Prod Chem Res 5: 275. doi:10.4172/2329-6836.1000275

Page 14 of 14

\section{References}

1. Morey-Gaines G (1982) Gymnodinium catenatum Graham (Dinophyceae): morphology and affinities with armoured forms. Phycologia 21: 154-163.

2. Hallegraeff GM, Blackburn SI, Doblin MA, Bolch CJS (2012) Global toxicology, ecophysiology and population relationships of the chain forming PST dinoflagellate Gymnodinium catenatum. Harmful Algae 14: 130-143.

3. Graham HW (1943) Gymnodinium catenatum, a new dinoflagellate from the Gulf of California. Trans Am Microsc Soc 62: 259-261.

4. Bolch CJ, Reynolds MJ (2002) Species resolution and global distribution of microreticulate dinoflagellate cysts. J Plankton Res 24: 565-578.

5. Band-Schmidt C, Bustillos-Guzmán J, Morquecho L, Gárate-Lizárraga I, Alonso-Rodríguez R, et al. (2006) Variations of PSP toxin profiles during different growth phases in Gymnodinium catenatum (Dinophyceae) strains isolated from three locations in the Gulf of California, Mexico. J Phycol 42: 757-768.

6. Yotsu-Yamashita M, Sugimoto A, Takai A, Yasumoto T (1999) Effects of specific modifications of several hydroxyls of tetrodotoxin on its affinity to rat brain membrane. J Pharmacol Exp Ther 289: 1688-1696.

7. Alexander J, Benford D, Cockburn A, Cravedi J, Dogliotti E, et al. (2009) Scientific opinion of the panel on contaminants in the food chain on request from the European commission on marine biotoxins in shellfishSaxitoxin Group. EFSAJ 1019: 1-76.

8. Ordas MC (2004) Toxin and molecular analysis of Gymnodinium catenatum (Dinophyceae) strains from Galicia (NW Spain) and Andalucia (S Spain). J Plankton Res 26: 341-349.

9. Band-Schmidt CJ, Morquecho L, Lechuga-Devéze $\mathrm{CH}$, Anderson DM (2004) Effects of growth medium, temperature, salinity and seawater source on the growth of Gymnodinium catenatum (Dinophyceae) from Bahia Concepcion, Gulf of California, Mexico. J Plankton Res 26: 1459-1470.

10. Band-Schmidt CJ, Bustillos-Guzman JJ, Hernandez-Sandoval FE, NunezVazquez EJ, Lopez-Cortes DJ (2014) Effect of temperature on growth and paralytic toxin profiles in isolates of Gymnodinium catenatum (Dinophyceae) from the Pacific coast of Mexico. Toxicon 90: 199-212.

11. Garate-Lizarraga I, Bustillos-Guzman JJ, Morquecho L, Band-Schmidt CJ Alonso-Rodriguez R, et al. (2005) Comparative paralytic shellfish toxin profiles in the strains of Gymnodinium catenatum Graham from the Gulf of California, Mexico. Mar Pollut Bull 50: 211-217.

12. Seok Jin O, Matsuyama Y, Yoon YH, Miyamura K, Choi CG, et al. (2010) Comparative analysis of paralytic shellfish toxin content and profile produced by dinoflagellate Gymnodinium catenatum isolated from Inokushi Bay, Japan. J Fac Agr Kyushu 55: 47-54.

13. Bustillos-Guzmán J, Band-Schmidt C, López-Cortés D, Gárate-Lizárraga I, Núñez-Vázquez E, et al. (2012) Variations in growth and toxicity in $G$. catenatum Graham of the Gulf of California under different proportions of nitrogen and phosphorus. Mar Sci 38: 101-117.

14. Cembella A (1998) Ecophysiology and metabolism of paralytic shellfish toxins in marine microalgae. Physiological Ecology of Harmful Algal Blooms, Springer-Verlag, Heidelberg, Anderson, DM, AD Cembella, GM Hallegraeff (Eds.), NATO-Advanced Study Institute Series 41: 381-404.
15. Negri A, Bolch C, Blackburn S, Dickman M, Llewellyn L, et al. (2000) Paralytic shellfish toxins in Gymnodinium catenatum strains from six countries, 9th International Conference-Harmful Algal Blooms 2001.

16. Negri A, Stirling D, Quilliam M, Blackburn S, Bolch A, et al. (2003) Three novel hydroxybenzoate saxitoxin analogues isolated from the dinoflagellate Gymnodinium catenatum. Chem Res Toxicol 16 1029-1033.

17. Llewellyn L, Negri A, Quilliam M (2004) High affinity for the rat brain sodium channel of newly discovered hydroxybenzoate saxitoxin analogues from the dinoflagellate Gymnodinium catenatum. Toxicon 43: 101-104.

18. Durán-Riveroll L, Allan Cembella, Band-Schmidt C, Bustillos-Guzmán J, Correa-Basurto J (2016) Docking simulation of the binding interactions of saxitoxin analogs produced by the marine dinoflagellate Gymnodinium catenatum to the voltage-gated sodium channel $\mathrm{Na}_{\mathrm{v}} 1.4$. Toxins 8: 129.

19. Negri AP, Bolch CJS, Geier S, Green DH, Park TG, et al. (2007) Widespread presence of hydrophobic paralytic shellfish toxins in Gymnodinium catenatum. Harmful Algae 6: 774-780.

20. Vale P (2008) Complex profiles of hydrophobic paralytic shellfish poisoning compounds in Gymnodinium catenatum identified by liquid chromatography with fluorescence detection and mass spectrometry. J Chromatogr A 1195: 85-93.

21. Vale P (2010) New saxitoxin analogues in the marine environment: developments in toxin chemistry, detection and biotransformation during the 2000s. Phytochem Rev 9: 525-535.

22. Bustillos-Guzman J, Vale P, Band-Schmidt C (2011) Presence of benzoate type toxins in Gymnodinium catenatum Graham isolated from the Mexican Pacific. Toxicon 57: 922-926.

23. Vale P (2008) Fate of benzoate paralytic shellfish poisoning toxins from Gymnodinium catenatum in shellfish and fish detected by pre-column oxidation and liquid chromatography with fluorescence detection. J Chromatogr A 1190: 191-197.

24. Blackburn SI, Bolch CJ, Haskard KA, Hallegraeff GM (2001) Reproductive compatibility among four global populations of the toxic dinoflagellate Gymnodinium catenatum (Dinophyceae). Phycologia 40: 78-87.

25. Diener M, Erler K, Christian B, Luckas B (2007) Application of a new zwitterionic hydrophilic interaction chromatography column for determination of paralytic shellfish poisoning toxins. J Sep Sci 30: 1821-1826.

26. Dell'Aversano C, Eaglesham GK, Quilliam MA (2004) Analysis of cyanobacterial toxins by hydrophilic interaction liquid chromatographymass spectrometry. J Chromatogr A 1028: 155-164.

27. Bovey FA, Mirau PA, Gutowsky H (1988) Nuclear magnetic resonance spectroscopy. (2nd edn), Elsevier, p: 653.

28. Durán-Riveroll LM, Peralta-Cruz J, Bustillos-Guzmán JJ, Band-Schmidt CJ (2013) Presence of benzoate-type toxins in a strain of Gymnodinium catenatum (Dinophyceae) isolated from Manzanillo, Colima, Mexico. Hidrobiológica 23: 169-175. 